\title{
PROSPECTS
}

\section{New shores of literature}

For good reading, look more deeply, says Paul Smaglik.

Summer, for me, means more than swapping teaching duties for camping, hiking and swimming; instead, I associate the sunny

season with reading. For other instructors - as well as for autodidacts - the obvious question is, what to read? But perhaps a more important question is, how should we read it?

Two recent articles, one in The Chronicle of Higher Education (http:// tinyurl.com/pagb2w) and another in Times Higher Education (http://tinyurl.com/o2cnw7), suggest that the way we read - as well as the ways in which we interact with other readers - could influence higher education as well as our careers and those of our students.

In the Chronicle article, author Rachel Toor talks about the typical graduate seminar student's knee-jerk tendency, when reviewing books, to try to slaughter sacred cows. She warns other instructors not to simply ask their students what they think of a particular author or article. "That generally leads to posturing, self-aggrandizing put-downs, and useless bluster," Toor writes. Instead, she asks students what they have learned from a particular writer, how the work fits in with or goes against recent trends and whether they can adapt a writing style, structure or strategy for their own work.

Instructors using this approach could buck the notion that personal pedagogical style in Britain is being threatened by bigger class sizes and larger teaching loads, which Rebecca Attwood writes about in the Times Higher Education piece. Creating a summer reading list with and for graduate and undergraduate students is one step towards closing that pedagogical gap. Asking students to answer questions about style, structure and argument - rather than about whether they agree or disagree with the writer improves education.

Applying this approach to our own reading can also improve our research and writing. Rather than simply agreeing or disagreeing with a journal article's argument, we can look for how the writer builds his or her case. Reading outside our discipline can also help our writing. Can we understand the thesis, even if we aren't familiar with the subject? Why, or why not?

Sometimes when we are too familiar with our areas of expertise, we assume all readers are on the same level. Writing a good journal article or grant application means spelling things out that the experts might know but that the larger audience we ultimately want to reach may not.

Finally, reading outside our discipline or speciality allows us to find connections that we might not make if we stay with more comfortable material. Adding a bit of literature or news to the mix can make summer reading less like work and more like a day at the beach. Paul Smaglik moderates Nature Networks Naturejobs career forum.

\section{POSTDOC JOURNAL}

\section{The little green monster}

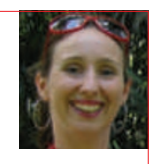

Towards the end of last year, my husband Brett and I discussed our options if one of us were offered a postdoc overseas. Disillusioned at the time with academia, I agreed to temporarily put aside my research career to be a stayat-home mum if he got a position first.

In retrospect, perhaps this declaration was rather rash. Now Brett has a postdoctoral fellowship in the United States and I really am a full-time mum. Reality has set in maybe I'm just not 'soccer mom' material?

To make matters worse, our new house has become a hub for disease ecology as Brett, his boss and two PhD students turn the garage into a lab and plan their experiments for the summer field season. I, on the other hand, contemplate such pressing issues as dealing with a case of viral tonsillitis and finding toddler-friendly activities in our neighbourhood while simultaneously learning to drive on the wrong side of the road.

When the conversation turns to what Brett and his colleagues have seen and caught in the field, I feel especially wistful; I love field work, but since I entered the realm of motherhood it has been the most difficult aspect of research to coordinate.

Although I truly appreciate being able to spend more quality time with my wonderful son Kai, I think I may have to squish the little green career monster inside a few more times, as I settle into my new role.

Joanne Isaac was a postdoc in climate-change effects on biodiversity at James Cook University, Townsville, Australia.
IN BRIEF

\section{Biotech audience shrinks}

If attendance at the Biotechnology Industry Organization annual conference is a barometer of the industry's health, then biotech is not doing well. Attendance at the 2009 event in Atlanta, Georgia, plummeted about $29 \%$ to 14,352 . Last year's meeting in San Diego, California, attracted 20,108 people.

Some attendees said the challenging economy made attendance essential. "It's more important than ever to be able to meet face to face with potential customers and partners," says Andrew Reaume, chief executive of Melior Discovery of Exton, Pennsylvania. On the positive side, fewer attendees meant short lines at the registration booth and the ubiquitous Starbucks kiosks. Next year's conference will be on 3-6 May in Chicago, Illinois.

\section{Boston ahead of the pack}

The metropolitan areas of Boston, Massachusetts; Philadelphia, Pennsylvania; and San Francisco, California, continue to lead the United States in sustaining and building their life-sciences sectors, according to a report from the Milken Institute, a think tank in Santa Monica, California.

The Greater Philadelphia Life Sciences Cluster 2009: An Economic and Comparative Assessment finds that Boston is ahead when it comes to research and development capacity and in success at getting funding from the National Science Foundation for submitted proposals. Greater San Francisco leads in the availability of risk capital and in relative growth.

\section{Show me the money}

US President Barack Obama's American Recovery and Reinvestment Act dedicated about US $\$ 21$ billion to federal research and development. Now, the US National Institutes of Health (NIH) and National Science Foundation (NSF) are helping potential recipients keep track of the funds. The NSF has a dedicated website (www.nsf.gov/recovery) that is publicizing money available to improve academic research facilities and research instrumentation. The NIH website also now provides a page (www.nih. gov/recovery/index.htm) for stimulus funding programmes. Under the stimulus funding plan, the agency will provide an additional $\$ 8.2$ billion in research grants. 